\title{
SOMATOTIPE DAN FISIOLOGI PEMAIN SEPAK BOLA
}

\author{
Al-Muqsith* \\ Bagian Anatomi Fakultas Kedokteran Universitas Malikussaleh \\ Lhokseumawe-Aceh Utara 24352, Indonesia \\ "Corresponding Author:al_muqsith2317@yahoo.co.id
}

\begin{abstract}
Abstrak
Antropometrik bermanfaat untuk memprediksi tipe-tipe tubuh yang sesuai dengan cabang olahraga yang dapat menunjang tercapainya prestasi yang maksimal. Setiap cabang olahraga mempunyai karakteristik yang berbeda, di mana untuk setiap masing-masing cabang olahraga memerlukan adanya kesesuaian tipe tubuh. Tipe tubuh yang cocok dengan cabang olahraga tertentu sangat berpengaruh terhadap pencapaian prestasi seorang atlet. Olahraga sepak bola didominasi oleh atlet dengan somatotipe mesomorphy dan mesomesomorphy. Pada atlet sepakbola yang sering menggunakan kemahiran tungkai dan kaki, maka struktur dan perkembangan fungsional organ tersebut akan lebih menonjol dibandingkan pada olahraga yang lain. Ada perbedaan dalam besar dan lemak badan antar pemain di posisi yang berbeda. penjaga gawang dan pemain belakang adalah pemain yang memiliki kekuatan lebih baik. Penjaga gawang memiliki waktu reaksi yang cepat dan biasanya lebih tinggi badannya dibanding rata-rata pemain lain. Seorang gelandang mengeluarkan energi lebih banyak dibanding posisi lainnya. Kelelahan paling dirasakan oleh center back (pemain belakang tengah) dan striker (penyerang) dibanding dengan gelandang, yang cenderung memiliki nilai $\mathrm{VO}_{2}$ maksimum lebih tinggi.
\end{abstract}

Kata Kunci : pemain sepak bola; somatotipe; tipe tubuh 


\title{
SOMATOTYPE AND PHYSIOLOGY OF FOOTBALL PLAYERS
}

\begin{abstract}
Anthropometric useful to predict the types of the body corresponding to the sport that can support the achievement of maximum performance. Each sport has different characteristics that each sport requires conformity body shape. Body type that corresponds to a particular sport greatly affect the achievement of an athlete.Football sport dominated by athletes with mesomorphy and mesomesomorphy somatotype. Football players often use the legs and feet so that the structure and development of the organ will be more dominant when compared to other sports. There are differences in fat composition and body size in accordance with its role of football players in each position. The goal keeper and defender player are the player who have a better strength. The goal keeper has a fast responce and higher weight than the other player with different position. The midfielder player use the higher energy than the other player with different position. Most fatique experirinced by center back and striker, who tend to have a high value of the maximum $\mathrm{VO}_{2}$.
\end{abstract}

Keywords: football player; somatotype, body tipe 


\section{Pendahuluan}

Sepakbola merupakan cabang olahraga yang sangat digemari oleh semua lapisan masyarakat di Indonesia, baik di kota-kota maupun di desa-desa, bahkan sekarang sepakbola digemari dan dimainkan oleh kaum wanita. Sepakbola merupakan salah satu cabang olahraga yang diprioritaskan untuk dibina, maka untuk meningkatkan dan mencapai prestasi alangkah baiknya jika semenjak anak-anak telah mendapatkan pendidikan olahraga dan khususnya sepakbola secara benar, teratur, dan terarah. Dewasa ini, permainan sepakbola bukan hanya sekedar hiburan atau pengisi waktu senggang, akan tetapi sudah dituntut untuk berprestasi setinggi-tingginya. Prestasi yang tinggi hanya dapat dicapai dengan latihanlatihan yang direncanakan dengan sistematis dan dilakukan secara terus menerus di bawah pengawasan dan bimbingan pelatih yang profesional. Mengingat kesenangan dan kecintaan masyarakat terhadap sepakbola, maka wajarlah bila para pembina sepakbola dituntut untuk terus membenahi diri dengan ilmu dan mencari pengalaman demi kemajuan sepakbola, apalagi sekarang ini sepakbola bisa digunakan sebagai bisnis, mencari pekerjaan, dan juga digunakan sebagai propaganda bagi perusahaan atau instansi yang membutuhkan popularitas dari masyarakat sehingga selalu ingin memenuhi kehendak dan kegemaran masyarakat melalui olahraga sepakbola. Menyadari akan keperluan itu berbagai usaha yang telah dan sedang dilakukan dalam rangka mencapai prestasi yang diinginkan, di antaranya adalah membuat atau menumbuhkan klub-klub persepakbolaan pada usia dini ${ }^{1}$.

Antropometrik tidak dapat menentukan prestasi atau penampilan olahragawan suatu cabang olahraga, tetapi antropometrik bermanfaat untuk memprediksi tipe-tipe tubuh yang sesuai dengan cabang olahraga yang dapat menunjang tercapainya prestasi yang maksimal. Setiap cabang olahraga mempunyai karakteristik yang berbeda, di mana untuk setiap masing-masing cabang olahraga memerlukan adanya kesesuaian perbandingan atau perimbangan tipe tubuh. Bentuk tubuh merupakan salah satu prasyarat untuk pencapaian prestasi yang maksimal².

Banyak bukti menunjukkan bahwa di antara atlet-atlet juara pada berbagai cabang olahraga terdapat ciri-ciri fisik dan fisiologi yang berbeda. Perbedaan ini tidak hanya pada atlet antar cabang olahraga, tetapi terdapat pula pada atlet cabang olahraga yang sama tergantung pada perbedaan posisi pemain ${ }^{3}$.

\section{Pembahasan}

Permainan sepakbola adalah cabang permainan beregu atau permainan tim, untuk mencapai kerja sama tim yang baik diperlukan pemain-pemain yang dapat menguasai semua bagian, macam-macam teknik dasar dan keterampilan bermain sepakbola, sehingga dapat memainkan bola dalam segala posisi dan situasi dengan cepat, tepat, dan cermat, artinya tidak membuang-buang energi dan waktu ${ }^{4}$.

Ada beberapa fakta dalam permainan sepak bola5:

- Pengeluaran energi membutuhkan sekitar 75\% $\mathrm{VO}_{2}$ maksimum; berbeda pada setiap posisi (gelandang mengeluarkan energi lebih banyak dibanding posisi lainnya).

- Denyut jantung rata-rata: 165 denyut per menit.

- Pemain menempuh jarak 8 sampai $12 \mathrm{~km}$ selama permainan.

- Dominansi kekuatan: paling tinggi pada badan dan tungkai serta kaki.

- Keterampilan yang paling membutuhkan keseimbangan pada 1 kaki; kekuatan dititikberatkan pada tungkai dan kaki. 
- Kelelahan paling dirasakan oleh center back (pemain belakang tengah) dan striker (penyerang) dibanding dengan gelandang, yang cenderung memiliki nilai $\mathrm{VO} 2$ maksimum lebih tinggi.

Sepakbola merupakan permainan yang dimainkan oleh dua regu yang masingmasing regu terdiri dari sebelas (11) orang pemain, yang lazim disebut kesebelasan. Masing-masing regu atau kesebelasan berusaha memasukan bola sebanyakbanyaknya ke dalam gawang lawan dan mempertahankan gawangnya sendiri agar tidak kemasukan ${ }^{6}$. Diperlukan beberapa faktor pendukung untuk menjadi seorang pemain bola yang baik, di antaranya faktor genetik, kedisiplinan dan latihan fisik, latihan khusus, lingkungan dan budaya, serta faktor yang tidak boleh dilupakan yaitu faktor keberuntungan. Faktor-faktor tersebut terdapat pada setiap pribadi. Jika seseorang bisa mengelolanya dengan baik maka orang tersebut berkemungkinan akan menjadi seorang pemain sepak bola yang baik.

\section{A. Faktor Genetika}

Kemampuan fisik dan postur tubuh setiap orang berbeda-beda. Hal ini disebabkan oleh genetika dari orang tuanya. Perbedaan tersebut dalam dunia sepak bola sangat mempengaruhinya. Apabila seorang pemain berpostur tubuh kecil maka pemain lawan akan sangat mudah menghentikannya karena lawan memiliki kekuatan yang lebih besar dan dia juga akan mengalami kesulitan dalam menjangkau bola-bola atas, tetapi pemain seperti ini biasanya memiliki kecepatan yang lebih baik. Begitu juga sebaliknya, pemain sepak bola yang memiliki ukuran tubuh terlalu besar akan memiliki kesulitan dan hambatan tersendiri dalam bermain sepak bola. Berbeda dengan pemain sepak bola yang memiliki tubuh ideal. Namun meski demikian, baik berpostur besar ataupun kecil, jika kita tetap mau berlatih maka segala kekurangan akan tertutupi ${ }^{7}$.

Pembinaan terhadap atlet tidak hanya dilakukan terhadap kemampuan teknik dan fisik pemain tetapi unsur struktur dan postur tubuh pemain juga perlu mendapat perhatian dalam proses pemilihan pemain. Postur tubuh merupakan salah satu aspek biologis dari penentu tercapainya prestasi dalam olahraga, keadaan tubuh merupakan unsur bawaan yang tidak bisa diubah oleh atlet. Struktur dan postur tubuh dalam pembinaan olahraga yang dimaksud oleh M. Anwar Pasau meliputi: 1) ukuran tinggi badan dan panjang tubuh, 2) ukuran besar dan lebar tubuh, 3) bentuk tubuh. Bentuk tubuh atau somatotipe adalah indeks spesifik yang menggambarkan perawakan seseorang, tinggi badan, berat badan dan kondisi tumpukan lemak tubuh seseorang. Baley (1986) membagi tipe bentuk tubuh atlet menjadi tiga, yaitu: 1) tipe mesomorphy, tipe ini ditandai dengan bahu lebar, pinggang cenderung kecil, bentuk kepala persegi serta perkembangan otot yang lebih besar, 2) tipe ectomorphy, tipe ini ditandai dengan permukaan kulit yang cenderung lebih luas dibanding dengan volume total tubuhnya dan badan kurus, 3) tipe endomorphy, tipe ini ditandai dengan tubuh yang volume batang tubuhnya cenderung lebih besar, bentuk bulat dan gemuk. Manusia tidak akan pernah mempunyai sifat-sifat jasmaniah yang sama persis dengan manusia lainnya sehingga dalam hal ini akan menyebabkan berbagai macam tipe bentuk tubuh atau somatotipe. Tipe tubuh yang cocok dengan cabang olahraga tertentu sangat berpengaruh terhadap pencapaian prestasi seorang olahragawan. Sejarah membuktikan bahwa orang telah lama berusaha menyelidiki penggolongan tipe tubuh (somatotype) tetapi penelitian tentang somatotipe yang terkait dengan kecocokan cabang olahraga masih sangat jarang untuk ditemukan. Somatotipe atau bentuk tubuh adalah keadaan tubuh dari seseorang yang 
pada awalnya sangat menentukan atau cocok karena sangat memungkinkan utuk melakukan aktivitas terhadap suatu cabang olahraga ${ }^{2}$.

Variabel-variabel struktur badan dapat dipakai untuk mendiskripsikan fisik manusia. Variabel-variabel ini juga dapat untuk membedakan antara laki-laki dan perempuan, dapat pula memberi informasi yang lebih lengkap antara atlet-atlet yang menonjol dan yang bukan atlet, serta pada atlet dengan cabang olahraga yang berbeda. Pada atlet sepakbola yang sering menggunakan kemahiran tungkai dan kaki, maka struktur dan perkembangan fungsional organ tersebut akan lebih menonjol dibandingkan pada olahraga yang lain. Kekuatan yang diperlukan pada olahraga sepakbola adalah kekuatan eksplosif, karena pada olahraga ini ada kontak fisik antar pemain, maka berat badan harus cukup, supaya tidak mudah kehilangan keseimbangan. Cara larinya pun sedemikian rupa dengan daya tahan yang diperoleh dengan latihan interval. Lebar pinggul yang besar diperlukan bagi seorang atlet sepakbola, terutama bagi pemain belakang8.

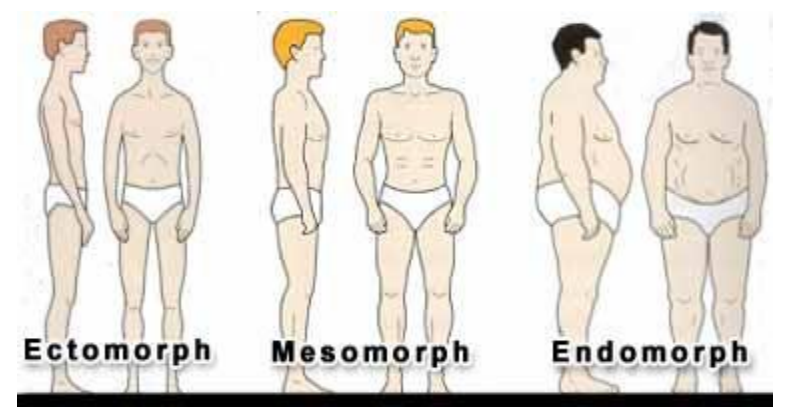

Gambar 1. Somatotype

Berdasarkan penelitian yang dilakukan oleh Neni Trilusiana Rahmawati pada tahun 1999 dengan melihat perbedaan ciri-ciri antropometrik dan komposisi badan antara pemain depan, tengah, belakang dan kiper pada 60 atlet sepakbola di Yogyakarta yang terbagi atas 18 pemain depan, 18 pemain tengah, 19 pemain belakang dan 5 kiper, dengan umur berkisar antara 17 - 32 tahun Berat dan tinggi badan, lebar bahu dan panggul, panjang trunkus serta lemak badan diukur dan dibandingkan antar pemain posisi yang berbeda, hasil penelitian menunjukkan bahwa kiper mempunyai besar badan, lebar bahu, lebar panggul, panjang trunkus (badan) dan lemak badan yang paling besar dibanding pemain posisi lain sehingga dalam hal ini terdapat perbedaan dalam besar dan lemak badan antar pemain beda posisi; secara keseluruhan distribusi somatotipe menunjukkan kesamaan dengan distribusi somatotipe atlet sepakbola dunia ${ }^{3}$.

\section{B. Kedisiplinan dan Latihan Fisik}

Kedisiplinan baik di dalam maupun di luar lapangan merupakan salah satu faktor penting untuk meningkatkan kemampuan seseorang dalam berlatih dan menerapkan latihan/ajaran yang diberikan, karena tanpa hal tersebut maka tidak mungkin seorang pemain bisa mencapai potensinya ${ }^{7}$.

Program latihan fisik sepak bola secara berkala adalah hal yang wajib dilakukan oleh para pemain sepak bola dan merupakan alat ukur dari ketahanan fisik seorang pemain sepak bola. Hal ini disebabkan karena ketahanan fisik menjadi modal utama untuk bisa menggiring dan menendang bola selama 90 menit waktu permainan. Latihan fisik juga dilakukan untuk mengantisipasi terjadinya cedera pada saat bertanding. Latihan fisik sepak bola bukan hal yang mutlak untuk keberhasilan seorang pemain, tetapi juga harus didampingi oleh pengalaman serta keahlian mengolah bola untuk mencetak seorang pemain sepak bola yang berkualitas9.

Latihan fisik sepak bola menitikberatkan pada beberapa aspek berikut ini ${ }^{9}$ :

1. Latihan fisik sepak bola yang menguatkan sistem kardiovaskular atau jantung. Latihan ini berfungsi melatih 
kekuatan jantung untuk menyuplai darah ke seluruh bagian tubuh. Latihan fisik ini dapat berupa lari di atas treadmill yang mengukur jarak yang ditempuh pemain dengan kecepatannya.

2. Latihan fisik sepak bola yang menguatkan paru-paru yang bertujuan supaya suplai oksigen terus berjalan secara maksimal. Beberapa tim sepak bola memilih lokasi pegunungan untuk latihan fisik ini. Hal ini berguna supaya paru-paru pemain bisa beradaptasi dengan lingkungan yang kadar oksigennya rendah.

3. Latihan fisik yang menguatkan organorgan yang berkaitan erat dengan sepak bola, seperti kaki, tangan, leher, dan kepala.

4. Latihan fisik dalam bentuk kelincahan. Memiliki otot saja tidak cukup bagi pemain sepak bola, sebab sepak bola juga dituntut untuk memiliki kelincahan. Program latihan fisik sepak bola biasanya dijadwalkan dalam sesi latihan di lapangan, digabungkan dengan latihan dasar dan simulasi permainan atau pertandingan sepak bola.

Tentu saja ada hal lain yang menjadi faktor pendukung program latihan fisik sepak bola, hal tersebut menyangkut dengan gaya hidup pemain sepak bola, seperti keseimbangan hidup dan pola asupan makanan. Oleh sebab itu, pemain sepak bola sangat dianjurkan untuk tidak merokok dan mengonsumsi minuman keras, sebab dua hal tersebut justru menjadi perusak dari dalam tubuh atlet itu sendiri ${ }^{9}$.

\section{Faktor Latihan Khusus}

Seorang pemain sepakbola selain harus menguasai teknik dasar yang benar juga harus mempunyai kondisi fisik yang baik. Komponen kondisi fisik yang sangat diperlukan meliputi: kekuatan, daya tahan, daya ledak, kecepatan, kelentukan, keseimbangan, koordinasi, kelincahan, ketepatan dan reaksi ${ }^{10}$.

Selain menguasai teknik dasar yang benar, pemain sepakbola juga harus mempunyai kondisi fisik yang baik. Dalam meningkatkan kondisi fisik maka perlu dilatihkan beberapa kondisi fisik, sedangkan unsur kondisi fisik umum meliputi kekuatan, daya tahan, kecepatan, kelincahan dan kelentukan. Sedangkan unsur kondisi fisik khusus mencakup stamina, daya ledak, reaksi, koordinasi, ketepatan, dan keseimbangan ${ }^{11}$.

Perlu diingat bahwa selama pertandingan sepak bola, kegiatan menendang, menyundul, dan memotong bola terjadi dengan cara yang tumpang tindih sehingga menimbulkan beban yang lebih besar pada sistem muskuloskeletal ${ }^{12}$. Kekuatan otot tungkai seseorang berperan penting dalam meningkatkan frekuensi langkah lari seseorang, karena frekuensi langkah adalah perkalian antara kekuatan otot tungkai dan kecepatan otot dalam melangkah. Kekuatan otot tungkai ini digunakan saat lari menggiring bola. Seorang pemain sepakbola harus memiliki kaki yang kuat, pergelangan kaki yang kuat, lutut yang kuat dan tungkai yang kuat agar dapat memikul badan yang berat. Dalam pencapaian kecepatan menggiring bola kelincahan dan kekuatan otot tungkai sangat berpengaruh. Karena otot merupakan faktor pendukung kemampuan seseorang untuk melangkahkan kaki. Faktor tersebut harus benar-benar diperhatikan secara seksama melalui pembinaan secara dini, serta memperhatikan postur tubuh, yang meliputi: a) ukuran tinggi badan dan panjang tubuh, b) ukuran besar, lebar dan berat tubuh, c) somatotype (bentuk tubuh: endomorphy, mesomorphy, dan ectomorphy ). Besar kecilnya otot benarbenar berpengaruh terhadap kekuatan otot. Para ahli fisiologi berpendapat bahwa pembesaran otot itu disebabkan oleh bertambah luasnya serabut otot akibat suatu 
latihan. Makin besar serabut-serabut otot seseorang, makin kuat pula otot tersebut ${ }^{10}$.

Kelincahan merupakan salah satu komponen kondisi fisik yang banyak dipergunakan dalam olahraga. Kelincahan kemampuan seseorang mengubah posisi di area tertentu. Seseorang yang mampu mengubah satu posisi yang berbeda dalam kecepatan tinggi dengan koordinasi yang baik, berarti kelincahannya cukup baik ${ }^{10}$. Kelincahan adalah kemampuan mengubah secara cepat arah tubuh atau bagian tubuh tanpa gangguan pada keseimbangan. Kelincahan sangat membantu foot work dalam permainan. Jadi jika kelincahan yang dimiliki seseorang semakin baik, maka foot work-nya semakin baik pula. Tanpa gerakan kaki yang lincah dan teratur, jangan mengharap atlet dapat bermain dengan baik. Gerakan kaki yang lincah dan teratur berarti atlet pada saat menggiring bola dapat merubah-ubah arah dan menghindari lawan dengan cepat. kelincahan diperlukan sekali dalam melakukan gerak tipu pada saat menggiring bola. Gerak tipu dapat kita kerjakan dengan mengendalikan ketepatan, kecepatan, dan kecermatan. Kegunaan kelincahan sangat penting terutama olahraga beregu dan memerlukan ketangkasan, khususnya sepakbola ${ }^{13}$. Kegunaan kelincahan adalah untuk mengkoordinasikan gerakan-gerakan berganda atau stimulan, mempermudah penguasaan teknik-teknik tinggi, gerakangerakan efisien, efektif, dan ekonomis serta mempermudah orientasi terhadap lawan dan lingkungan ${ }^{11}$.

Adapun faktor-faktor yang mempengaruhi kelincahan adalah ${ }^{13}$ :

a. Tipe tubuh

Seperti telah dijelaskan dalam pengertian kelincahan bahwa gerakangerakan kelincahan menuntut terjadinya pengurangan dan pemacuan tubuh secara bergantian. Di mana momentum sama dengan massa dikalikan kecepatan.
Dihubungkan dengan tipe tubuh, maka orang yang tergolong mesomorfi dan mesoektomorfi lebih tangkas dari ektomorf dan endomorf.

b. Usia

Kelincahan anak meningkat sampai kira-kira usia 12 tahun (memasuki pertumbuhan cepat). Selama periode tersebut (3 tahun) kelincahan tidak meningkat, bahkan menurun. Setelah masa pertumbuhan berlalu, kelincahan meningkat lagi secara mantap sampai anak mencapai maturitas dan setelah itu menurun kembali.

c. Jenis kelamin

Anak laki-laki menunjukkan kelincahan sedikit lebih baik dari pada anak wanita sebelum mencapai usia pubertas. Setelah pubertas perbedaan tampak lebik mencolok.

d. Berat badan

Berat badan yang berlebihan secara langsung mengurangi kelincahan.

e. Kelelahan

Kelelahan mengurangi ketangkasan terutama karena menurunkan koordinasi. Sehubungan dengan hal itu, penting untuk memelihara daya tahan kardiovaskuler dan otot agar kelelahan tidak mudah timbul.

Unsur gerak kecepatan merupakan unsur dasar setelah kekuatan dan daya tahan yang berguna untuk mencapai prestasi maksimal. Pada banyak cabang olahraga, kecepatan merupakan komponen kondisi fisik yang mendasar, sehingga kecepatan merupakan faktor penentu dalam cabang olahraga seperti nomor-nomor lari jarak pendek, renang, olahraga bela diri, dan cabang olah raga permainan. Kecepatan adalah kemampuan untuk melakukan gerakan-gerakan yang sejenis secara berturut-turut dalam waktu yang sesingkatsingkatnya atau kemampuan untuk menempuh suatu jarak yang sesingkatsingkatnya ${ }^{14}$. 
Kecepatan dalam hal ini dapat dibedakan menjadi 3, yaitu11:

\section{Kecepatan sprint}

Kecepatan sprint adalah kemampuan organisme atlet bergerak ke depan dengan kekuatan dan kecepatan maksimal untuk mencapai hasil yang sebaik-baiknya.

\section{Kecepatan reaksi}

Kecepatan reaksi adalah kemampuan organisme atlet untuk menjawab suatu rangsang secepat mungkin dalam mencapai hasil yang sebaik-baiknya.

3. Kecepatan bergerak

Kecepatan bergerak adalah kemampuan organisme atlet untuk bergerak secepat mungkin dalam satu gerakan yang tidak terputus.

Di antara tipe kecepatan tersebut di atas, 2 tipe kecepatan yaitu kecepatan reaksi dan kecepatan bergerak sangat diperlukan dalam kegiatan olahraga sepak bola, misalnya seorang pemain sepak bola pada saat menggiring bola lalu mengoper kepada kawan dan sesaat kemudian dikembalikan lagi kedepannya dan bola harus dikejar, artinya pemain tersebut sudah melakukan gerakan dengan gerakan secara cepat, karena harus mendahului lawan yang akan datang. Dalam permainan sepakbola, kedua tipe kecepatan di atas banyak digunakan mulai dari menggiring bola, memberi umpan kepada kawan, saat menendang bola bahkan saat melakukan gerakan tanpa bola pun seorang pemain harus sesering mungkin melakukan gerakan.

Seorang atlet paling tidak memiliki empat aspek pokok yang dikuasai dengan optimal, yaitu2: 1) teknik, 2) fisik, 3) taktik, 4) psikis. Unsur teknik atau keterampilan dalam permainan sepakbola, yang harus dikuasai yaitu: (1) menedang bola, (2) menahan bola, (3) menggiring bola, (4) menyundul bola, (5) gerak tipu, (6) merebut bola, (7) lemparan ke dalam, (8) teknik penjaga gawang. Dalam sepak bola, menendang digunakan untuk memberi umpan dan menembak bola. Komponen menendang meliputi jarak, akurasi, dan kecepatan. Hal yang relatif penting dari masing-masing komponen memberi umpan dan menembak bola adalah segala sesuatu yang berhubungan dengan kondisi permainan saat bola ditendang ${ }^{15}$. Seorang penjaga gawang membutuhkan teknik khusus dalam menjalankan tugasnya di antaranya menangkap bola bergulir di tanah, bola melambung ke arah perut, dada atau kepala, bola lambung di atas kepala, yang lainnya yaitu menjatuhkan badan atau diving untuk menyelamatkan gawang dari terciptanya gol, teknik melempar dan menendang bola untuk memberi umpan dan memulai permainan, serta penempatan posisi yang baik untuk memudahkan penjaga gawang dalam melakukan berbagai penyelamatan dan penyempitan sudut ruang tembak pemain lawan. Komponen fisik yang mendukung penampilan penjaga gawang di antaranya adalah kemampuan melompat ke atas, kemampuan melompat ke samping, kecepatan reaksi, kecepatan sprint jarak pendek di area gawang, ketepatan membaca arah bola, koordinasi dan kekuatan. Seorang penjaga gawang membutuhkan gerakan yang lebih kompleks dibanding pemain bukan penjaga gawang seperti pemain tengah atau pemain belakang. Beberapa penelitian terhadap penjaga gawang sudah pernah dilakukan di antaranya menyatakan bahwa penjaga gawang dan pemain belakang adalah pemain yang memiliki kekuatan lebih baik. Penjaga gawang memiliki waktu reaksi yang lebih pendek dan biasanya lebih tinggi badannya dibanding rata-rata pemain lain ${ }^{2}$.

\section{Lingkungan dan Budaya}

Olahraga dalam kalangan masyarakat sangat digemari bahkan sampai dipopulerkan, supaya mampu mendapatkan suatu hubungan timbal balik dalam kaitannya antara budaya dan masyarakat. 
Olahraga dapat mempersatukan keseluruhan itu. Misalnya, dalam olahraga sepakbola, walaupun kalangan masyarakat dalam hal etnis budayanya berbeda namun tidak pada olahraga sepakbola. Kalangan masyarakat mampu berbaur menjadi dan satu tidak membedakan satu sama lain, apakah dari etnis mana dan budaya mana. Mereka semua berbaur menjadi satu untuk mewujudkan suatu olahraga yang bersamaan dapat menjadi kompleks, sehingga mampu memajukan dunia olahraga ${ }^{16}$.

Lingkungan sosial budaya banyak pengaruh dalam keterampilan gerak. Di Indonesia muncul bukti-bukti yang banyak secara umum misalnya dari beberapa etnis di Indonesia sangat berpengaruh pada ketrampilan motorik antara kulit hitam dan kulit putih, walaupun sebenarnya di Indonesia tergolong dalam kulit sawo matang. Contohnya saja dalam cabang olahraga, di Indonesia tidak semua ras atau suku sama dalam cabang olahraga. Misalnya suku Maluku, sebagian penduduknya identik dengan olahraga tinju, sedangkan suku jawa sebagian identik dengan olahraga badminton. Disitulah perbedaan yang dapat dilihat melalui perbedaan suku. Studi antropologi mengungkapkan kelebihan manusia dan makhluk lainnya di muka bumi. Manusia memiliki kemampuan untuk mengekplorasi dan mengeksplotasi lingkungan di sekitarnya ${ }^{16}$.

Dalam olahraga sepak bola di Indonesia, kita dapat melihat atlet-atlet yang berasal dari bagian timur seperti papua dan maluku memiliki postur tubuh yang lebih ideal dan memiliki kekuatan fisik yang lebih baik dibandingkan pemain dari daerah lain. Hal ini mungkin disebabkan karena mereka bertempat tinggal di daerah yang relatif tinggi (pegunungan) sehingga tubuhnya telah beradaptasi untuk memiliki tubuh yang besar dan lebar serta memiliki kekuatan fisik dan kapasitas paru yang lebih baik dibandingkan dengan pemain yang berasal dari daerah yang lain.

\section{Kesimpulan}

Antropometrik tidak dapat menentukan prestasi atau penampilan olahragawan suatu cabang olahraga, tetapi antropometrik bermanfaat untuk memprediksi tipe-tipe tubuh yang sesuai dengan cabang olahraga yang dapat menunjang tercapainya prestasi yang maksimal. Setiap cabang olahraga mempunyai karakteristik yang berbeda, di mana untuk setiap masing-masing cabang olahraga memerlukan adanya kesesuaian perbandingan atau perimbangan tipe tubuh. Bentuk tubuh merupakan salah satu prasyarat untuk pencapaian prestasi yang maksimal. Manusia tidak akan pernah mempunyai sifat-sifat jasmaniah yang sama persis dengan manusia lainnya sehingga dalam hal ini akan menyebabkan berbagai macam tipe bentuk tubuh atau somatotipe. Tipe tubuh yang cocok dengan cabang olahraga tertentu sangat berpengaruh terhadap pencapaian prestasi seorang olahragawan. Baley membagi tipe bentuk tubuh atlet menjadi tiga, yaitu: 1) tipe mesomorphy, 2) tipe ectomorphy, 3) tipe endomorphy. Dihubungkan dengan tipe tubuh, maka orang yang tergolong mesomorphy dan mesomesomorphy lebih tangkas dari ectomorphy dan endomorphy sehingga olahraga sepak bola didominasi oleh atlet dengan somatotipe mesomorphy dan mesomesomorphy.

Diperlukan beberapa faktor pendukung untuk menjadi seorang pemain bola yang baik, di antaranya faktor genetik, kedisiplinan dan latihan fisik, latihan khusus, lingkungan dan budaya serta faktor keberuntungan. Pada atlet sepakbola yang sering menggunakan kemahiran tungkai dan kaki, maka struktur dan perkembangan fungsional organ tersebut akan lebih menonjol dibandingkan pada olahraga yang lain. Kekuatan yang diperlukan pada 
olahraga sepakbola adalah kekuatan eksplosif, karena pada olahraga ini ada kontak fisik antar pemain, maka berat badan harus cukup, supaya tidak mudah kehilangan keseimbangan. Cara larinya pun sedemikian rupa dengan daya tahan yang diperoleh dengan latihan interval. Lebar pinggul yang besar diperlukan bagi seorang atlet sepakbola, terutama bagi pemain belakang. kiper mempunyai besar badan, lebar bahu, lebar panggul, panjang trunkus (badan) dan lemak badan yang paling besar dibanding pemain posisi lain sehingga dalam hal ini terdapat perbedaan dalam besar dan lemak badan antar pemain beda posisi. penjaga gawang dan pemain belakang adalah pemain yang memiliki kekuatan lebih baik. Penjaga gawang memiliki waktu reaksi yang cepat dan biasanya lebih tinggi badannya dibanding rata-rata pemain lain. Seorang gelandang mengeluarkan energi lebih banyak dibanding posisi lainnya. Kelelahan paling dirasakan oleh center back (pemain belakang tengah) dan striker (penyerang) dibanding dengan gelandang, yang cenderung memiliki nilai VO2 maksimum lebih tinggi.

\section{Daftar Pustaka}

1. Skripsi Mulyono. Hubungan Antara Kekuatan Otot Tungkai dan Kelincahan dengan Kecepatan Menggiring Bola Pada Siswa Lembaga Pendidikan Sepak Bola (LPSB) UNDIP Semarang. Semarang: UNNES, 2005. Diunduh: 28 Juni 2012 dari http:/ / cochoskripsi.blogspot.com/2012 /02/contoh-skripsi-sepakbola.html.

2. Karya Ilmiah Primasoni, N. dan Sulistiyono. 2010. Somatotype Penjaga Gawang Unit Kegiatan Mahasiswa Sepakbola UNY Tahun 2010/2011. Hal. 3-16, 2010.

3. Rahmawati, NT. Ciri-ciri antropometrik dan komposisi badan pada atlet sepakbola di Yogyakarta. Berkala Ilmu Kedokteran,1999; XXXI(2).
4. Sukatamsi. Teknik Dasar Bermain Sepakbola. Solo: Tiga Serangkai, Hal.12, 1984

5. Madden, CC., Putukian, M. et al. Netter's Sports Medicine. Philadelphia: Elvesier Saunders. Hal. 59, 2010.

6. Sarumpat. Permainan Besar. Jakarta: Departemen Pendidikan dan Kebudayaan, 1992.

7. Riana, E. Kunci Sukses Bermain Sepak Bola, 2012 dikutip : http://my.opera.com/erikriana/blog/ 2011/01/02/kunci-sukses-bermainsepakbola.

8. Rahmawati NT. Beberapa Ukuran Antropometri pada Atlet Sepakbola dan Bulutangkis di Yogyakarta. Berkala Ilmu Kedokteran, 1996; Vol. 28, No. 2, Hal. 72-78.

9. Ahira, A. Program Latihan Fisik Sepak Bola, 2012. Diunduh: 28 Juni 2012 dari http://anneahira.com/programlatihan-fisik-sepak-bola/

10. Sajoto, M. Peningkatan dan Pembinaan Kekuatan Kondisi Fisik. Semarang: Dahara Prize, 1988. Hal. 9, 11-13, 56, 111.

11. Suharno Hp. Ilmu Kepelatihan Olahraga. Yogyakarta: FPOK IKIP Yogyakarta, 1985. Hal. 31-33.

12. Magee, D. J., Manske, R. et al. Athletic And Sport Issues in Musculoskeletal Rehabilitation. St. Louis, Missouri: Elvesier Saunders, 2011. Hal. 288.

13. Moeloek, D., Tjokro, A. Kesehatan Olahraga. Jakarta: FK UI Jakarta, 1984. Hal. 8-9.

14. Harsono. Coaching dan Aspek-Aspek Psikologi Dalam Choaching. Jakarta: Depdikbud, Dirjen Dikti P2LPTK, 1988. Hal. 21.

15. Adrian, M. J., Cooper, J.M. Biomechanics of Human Movement. United States of America: WCB Brown \& Benchmark, 1995. Hal. 387. 
16. Pradipta, G. D. Olahraga dan Antropologi, 2011. Diunduh: 28 Juni 2012 dari http://galihdwipradipta. blogspot.com/ 
